\title{
Ephrin-B2/Fc promotes proliferation and migration, and suppresses apoptosis in human umbilical vein endothelial cells
}

\author{
Li-Chun Zheng ${ }^{1,2, *}$, Xiao-Qing Wang ${ }^{2, *}$, Kun Lu $^{3, *}$, Xiao-Ling Deng ${ }^{3}$, Cheng-Wei \\ Zhang ${ }^{4}$, Hong Luo ${ }^{2}$, Xu-Dong $\mathrm{Xu}^{2}$, Xiao-Man Chen ${ }^{2}$, Lu Yan ${ }^{5}$, Yi-Qing Wang ${ }^{2}$ and \\ Song-Lin Shi ${ }^{3}$ \\ ${ }^{1}$ Medical College of Xiamen University, Jinshan Community Health Service Center, Xiamen Traditional Chinese Medical \\ Hospital, Xiamen 361000, P.R. China \\ ${ }^{2}$ Xiamen Heart Center, Medical College of Xiamen University, Xiamen 361000, P.R. China \\ ${ }^{3}$ Department of Basic Medicine, Medical College of Xiamen University, Cancer Research Center of Xiamen University, Xiamen \\ 361102, P.R. China \\ ${ }^{4}$ Department of Cardiology, Affiliated Dongnan Hospital of Xiamen University, Zhangzhou 363000, P.R. China \\ ${ }^{5}$ Department of Basic Medicine, Medical College of Xiamen University, Xiamen 361102, P.R. China \\ *These authors have contributed equally to this work \\ Correspondence to: Yi-Qing Wang, email: wang_gina@163.com \\ Song-Lin Shi, email: shisonglin@xmu.edu.cn
}

Keywords: ephrin-B2, proliferation, migration, human umbilical vein endothelial cell, proteomic analysis

Received: December 09, $2016 \quad$ Accepted: April 03, $2017 \quad$ Published: April 20, 2017

Copyright: Zheng et al. This is an open-access article distributed under the terms of the Creative Commons Attribution License (CC-BY), which permits unrestricted use, distribution, and reproduction in any medium, provided the original author and source are credited.

\section{ABSTRACT}

Tumor growth and metastasis are angiogenesis dependent. Angiogenic growth involves endothelial cell proliferation, migration, and invasion. Ephrin-B2 is a ligand for Eph receptor tyrosine kinases and is an important mediator in vascular endothelial growth factor-mediated angiogenesis. However, research offer controversial information regarding effects of ephrin-B2 on vascular endothelial cells. In this paper, proteome analyses showed that ephrin-B2/FC significantly activates multiple signaling pathways related to cell proliferation, survival, and migration and suppresses apoptosis and cell death. Cytological experiments further confirm that ephrin-B2/ Fc stimulates endothelial cell proliferation, triggers dose-dependent migration, and suppresses cell apoptosis. Results demonstrate that soluble dose-dependent ephrinB2 can promote proliferation and migration and inhibit apoptosis of human umbilical vein endothelial cells. These results also suggest that ephrinB2 prevents ischemic disease and can potentially be a new therapeutic target for treating angiogenesisrelated diseases and tumors.

\section{INTRODUCTION}

Tumor growth and metastasis are angiogenesis dependent. Blood vessels support cancer cells with nutrients and allow communication between primary and metastatic tumors [1-3]. Anti-angiogenesis is an efficient antitumor strategy for its protective effects against tumor emergence and progression [4-6]. Tyrosine protein kinase family includes ephrin and its receptor Eph as leading members and is considered as key factor for angiogenesis and lymphatic valve development $[7,8]$. As one of the key genes in angiogenesis [9], ephrin-B2 is very important in regulating embryonic and adult angiogenesis and tumor angiogenesis [10-12].

Ephrin-B2 is variably expressed in tumor cells and mediates tumor cell proliferation, invasion, and migration $[13,14]$. Through Src-extracellular-signal-regulated kinase (ERK) pathway, 5-fluorouracil-induced ephrin-B2 reverse signaling promotes tumorigenesis and drives epithelialmesenchymal transition via Src-focal adhesion kinase (FAK) pathway [15]. Soluble ephrinB2 inhibits xenograft growth of head-and-neck squamous cell carcinoma [16]. Some studies showed that ephrin-B2 is a poor prognostic indicator of solid tumors, including head-and-neck 
squamous cell carcinoma, pancreatic adenocarcinoma, bladder urothelial carcinoma, and thyroid carcinoma [14, 17-19]

Vascular endothelial growth factor (VEGF) is the most potent cytokine involved in tumor angiogenesis and metastasis. VEGF-A binds to its receptor VEGFR2, induces VEGFR2 endocytosis, and promotes survival, proliferation, vessel sprouting, and permeability of endothelial cell vessels [12, 20, 21]. Ephrin-B2 was proven to be involved in VEGF/VEGFR-mediated angiogenesis. Ephrin-B2 promotes VEGFR endocytosis in endothelial cells, thereby enhancing VEGF-mediated angiogenesis $[12,22]$, which is essential in normal and pathological situations [23, 24].

Migration and proliferation of endothelial cells are prerequisites of solid tumor angiogenesis. However, research offer controversial information regarding effects of ephrin-B2 on vascular endothelial cells. Some studies showed that ephrin-B2 promotes migration and proliferation of endothelial cells [25-27]. On the other hand, other studies drew different conclusions [16, 28]. Systematic research is still needed to further clarify mechanisms of ephrin-B2 and its effects on endothelial cells.

In the present study, by using quantitative global and phosphorylated proteomics technological methods associated with bioinformatics analysis, we systematically and comprehensively revealed effects of ephrin-B2 on cellular functions and signaling pathways of human umbilical vein endothelial cells (HUVECs). Results showed that ephrin-B2 promoted proliferation, survival, migration, cell cycle, and suppressed apoptosis of HUVECs. Similar results were observed in further cellular experiments. These data suggest that ephrinB2 plays a protective role in ischemic disease and can potentially be a new therapeutic target for treating angiogenesis-related diseases and tumors.

\section{RESULTS}

\section{Identification and quantification of differentially expressed proteins induced by ephrin-B2 treatment}

To study the effect of ephrin-B2 on HUVECs, we isolated and identified primary HUVECs from freshly isolated umbilical cords. Immunohistochemical results demonstrated positive expression of factor-VIII-related antigen in isolated cells (Supplementary Figure 1); this positive expression proved successful isolation of HUVECs. HUVECs were cultured in stable isotope labeling by amino acids in cell culture (SILAC) media and treated with ephrin-B2/Fc or phosphate-buffered saline (PBS) for $15 \mathrm{~h}$. Global and phosphorylated proteins were then prepared and subjected to liquid chromatography tandem-mass spectrometry analysis. Among 1720 global proteins identified, 258 were differentially expressed; 134 proteins increased, whereas 124 proteins decreased. For phosphorylated proteins, 395 differentially expressed proteins were identified from 1377 phosphorylated sites. According to phosphorylation level, 354 proteins were upregulated, whereas 41 proteins were down-regulated.

\section{Functional analyses: Ephrin-B2 promoted proliferation and migration and suppressed apoptosis in HUVECs}

To functionally characterize differentially expressed proteins, we used Ingenuity Pathway Analysis (IPA) to associate these proteins to certain molecular and cellular functions in the Ingenuity Knowledge Base database. $p$ value was calculated using right-tailed Fisher's exact test to assess association level. Functions were arranged per $-\log (p$-value $)$. As shown in Figure 1A, for differentially expressed global proteins, the top five molecular and cellular functions were post-translational modification, protein folding, cell death and survival, cell-to-cell signaling and interaction, and cellular assembly and organization. For differentially expressed phosphorylated proteins, the top five molecular and cellular functions were gene expression, cellular growth and proliferation, cellular assembly and organization, cellular function and maintenance, and cell death and survival (Figure 1B). Among these functions, cell death and survival (labeled with dotted box) exhibited relatively high association levels and differential molecules in both global and phosphorylated proteins. Cellular growth and proliferation presented the highest number of differential molecules (215) in phosphorylated proteins. Z-scores were calculated according to expression level (up or down) of corresponding molecules in experiments and expected expression values (up or down) in pathways or functions. Z-scores $\geq 2(\leq-2)$ indicate that function or signaling pathway is statistically and significantly activated (inhibited). As listed in the tables (Tables 1 and 2 and Supplementary Tables 3 and 4), with high absolute values of z-scores $(\mid z$-score $\mid \geq 2)$, ephrin-B2 suppressed cell apoptosis $(\mathrm{z}=-3.563 /-2.329)$ and death $(\mathrm{z}=-3.5373 /$ $-2.938)$ and promoted cell survival $(z=2.8823 / 3.825)$, proliferation $(\mathrm{z}=2.425 / 3.818)$, movement $(\mathrm{z}$ $=4.2183 / 3.118)$, and migration $(\mathrm{z}=3.9823 / 3.194)$. Ephrin-B2 also promoted angiogenesis $(z=2.928)$ in phosphorylated proteins (Supplementary Table 4).

\section{Signal pathway analyses: Ephrin-B2 activated signaling pathways involved in cell growth, proliferation, and movement}

Among signaling pathways involving differentially expressed global proteins, endothelial nitric oxide synthase (eNOS) signaling showed the highest association level and z-score (2.236), indicating activation of this 


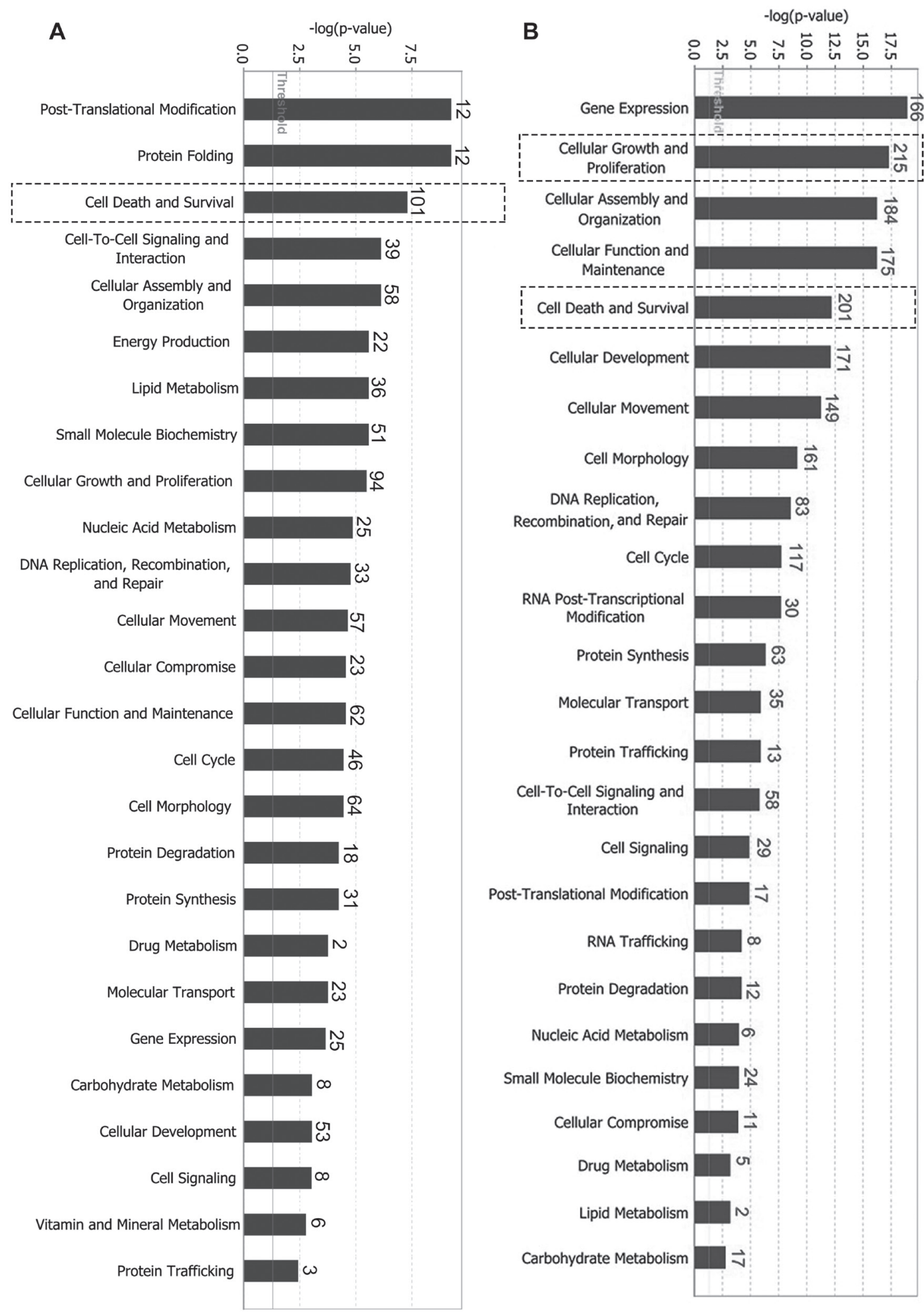

Figure 1: Differentially expressed proteins mainly participate in cell growth and proliferation, death and survival, cell movement, and other biological functions. (A) Molecular and cellular functions involving differentially expressed global proteins; (B) Molecular and cellular functions involving differentially expressed phosphorylated proteins. $p$-value was calculated using right-tailed Fisher's exact test to assess association level. Functions were arranged according to $-\log (p$-value). Threshold line indicating significant level was set at $p=0.05$, or $-\log (p$-value $)=1.3$ means. The number on top of bar represents differentially expressed proteins involved in specific molecular pathways. 
Table 1: Significant biological functions associated with differentially expressed global proteins

\begin{tabular}{llcc}
\hline Function Annotation & p-value & Predicted activation state & z-score \\
\hline Apoptosis & $1.51 \mathrm{E}-06$ & Inhibited & -3.563 \\
Cell Death & $4.97 \mathrm{E}-08$ & Inhibited & -3.5373 \\
Necrosis & $1.57 \mathrm{E}-05$ & Inhibited & -3.074 \\
Cell Survival & $6.26 \mathrm{E}-03$ & Activated & 2.8823 \\
Cell Movement & $6.05 \mathrm{E}-05$ & Activated & 4.2183 \\
Migration of Cells & $2.27 \mathrm{E}-05$ & Activated & 3.9823 \\
Proliferation of Epidermal Cells & $7.32 \mathrm{E}-03$ & Activated & 2.425 \\
Reorganization of Cytoskeleton & $7.53 \mathrm{E}-04$ & Activated & 2.194 \\
Organization of Cytoplasm & $2.11 \mathrm{E}-04$ & Activated & 2.036 \\
Organization of Cytoskeleton & $3.59 \mathrm{E}-04$ & Activated & 2.074 \\
Migration of Endothelial Cells & $2.07 \mathrm{E}-03$ & Activated & 2.013 \\
\hline
\end{tabular}

Note: "Function annotation" includes biological functions involving differentially expressed proteins. $p$-value represents matching contingency of data, and corresponding function, $\mid z$-score $\mid \geq 2$ is considered as prediction index of downstream effect.

Table 2: Significant biological functions associated with differentially expressed phosphorylated proteins

\begin{tabular}{llll}
\hline $\begin{array}{l}\text { Diseases or Functions } \\
\text { Annotation }\end{array}$ & $\boldsymbol{p}$-Value & Predicted Activation State & z-score \\
\hline Proliferation of Cells & $5.43 \mathrm{E}-18$ & Activated & 3.818 \\
Pericardial Effusion & $3.24 \mathrm{E}-03$ & Inhibited & -2.000 \\
Cardiomyopathy & $5.74 \mathrm{E}-04$ & Inhibited & -2.093 \\
Development of & $8.24 \mathrm{E}-05$ & Activated & 2.398 \\
Cardiovascular System & $2.81 \mathrm{E}-04$ & Activated & 2.928 \\
Angiogenesis & $1.67 \mathrm{E}-03$ & Activated & 2.120 \\
Development of Blood & $7.37 \mathrm{E}-07$ & Activated & 2.623 \\
Vessel & $1.97 \mathrm{E}-05$ & Activated & 2.959 \\
Interphase & $2.76 \mathrm{E}-05$ & Activated & 3.825 \\
G1 Phase & $6.58 \mathrm{E}-13$ & Inhibited & -2.938 \\
Cell Survival & $7.07 \mathrm{E}-13$ & Inhibited & -2.329 \\
Cell Death & $1.18 \mathrm{E}-04$ & Activated & 3.916 \\
Apoptosis & $5.76 \mathrm{E}-12$ & Activated & 3.118 \\
Cell Viability & $2.04 \mathrm{E}-11$ & Activated & 3.194 \\
Cell Movement & $1.18 \mathrm{E}-04$ & Inhibited & -2.473 \\
Migration of Cells & $1.45 \mathrm{E}-08$ & Activated & 2.163 \\
Edema & & & \\
Repair of DNA & & & \\
\hline
\end{tabular}


pathway (Figure 2, Table 3, and Supplementary Table 5). Rho GTPases showed the highest association level among signaling pathways involving differentially expressed phosphorylated proteins. Many important signaling pathways showed significant association and were activated in phosphorylated proteins (Figure 3,
Table 4, and Supplementary Table 6). These signaling pathways include integrin signaling, GA12/13 signaling, telomerase signaling, ERK5 signaling, insulin-like growth factor 1 (IGF-1) signaling, Rac signaling, ERK/mitogenactivated protein kinase (MAPK) signaling, VEGF signaling, hepatocyte growth factor (HGF) signaling, and

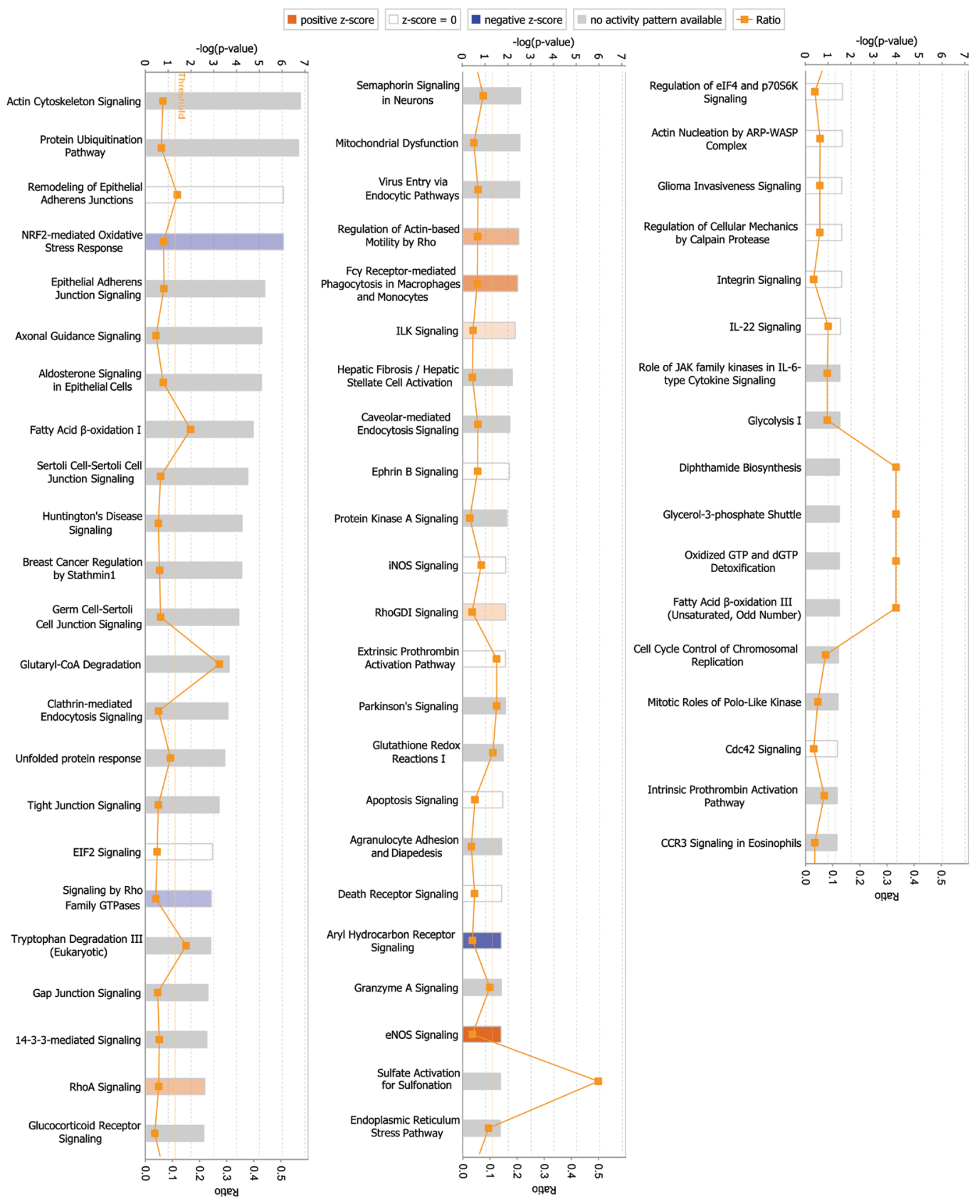

Figure 2: Signaling pathways associated with differentially expressed global proteins. Among signaling pathways associated with differentially expressed global proteins, eNOS signaling exhibited the highest correlation and z-score (2.236), indicating pathway activation. $p$-value was calculated using right-tailed Fisher's exact test to assess association level. $p<0.05$ or $-\log (p$-value) $>1.3$ (the main axis or bar chart) signifies significant association. Threshold line indicating significant level was set at $p=0.05$ or $-\log (p$-value $)$ $=1.3$ means. Z-score is calculated according to expression level (up or down) of corresponding molecules in experiments and expected expression value (up or down) in pathways. Z-scores $\geq 2$ or $\leq-2$ indicate that signaling pathway was statistically and significantly activated (colored in yellow) or inhibited (colored in blue). The ratio denotes proportion of differentially expressed genes in total signaling pathway genes; such ratio is provided as reference for significance assessment. 
Table 3: Significant canonical pathways associated with differentially expressed global proteins

\begin{tabular}{lccc}
\hline $\begin{array}{l}\text { Ingenuity Canonical } \\
\text { Pathways }\end{array}$ & $-\log (\boldsymbol{p}$-value $)$ & Ratio & z-score \\
\hline eNOS Signaling & $1.68 \mathrm{E} 00$ & $3.55 \mathrm{E}-02$ & 2.236 \\
PPAR $\alpha / R X R \alpha$ Activation & $1.3 \mathrm{E} 00$ & $2.79 \mathrm{E}-02$ & 1.342 \\
$\begin{array}{l}\text { Regulation of Actin-based } \\
\text { Motility by Rho }\end{array}$ & $2.45 \mathrm{E} 00$ & $5.49 \mathrm{E}-02$ & 1.000 \\
$\begin{array}{l}\text { RhoA Signaling } \\
\text { NRF2-mediated Oxidative }\end{array}$ & $2.61 \mathrm{E} 00$ & $4.92 \mathrm{E}-02$ & 0.816 \\
Stress Response & $6.06 \mathrm{E} 00$ & $6.67 \mathrm{E}-02$ & -0.447 \\
\hline
\end{tabular}

phosphoinositide-3-kinase (PI3K)/AKT signaling. These pathways are mainly involved in cell growth, proliferation, movement, and oxidative stress.

\section{Interaction network analyses indicated that ephrin-B2 participated in multiple cellular functions}

To characterize the effects of ephrin-B2 on HUVECs by functional protein groups, identified differentially expressed proteins, called focus genes in IPA, were used as starting point to generate biological networks defined by the Ingenuity Knowledge Base database. Out of 258 differentially expressed global proteins, 79 were mapped to four highly significant networks (score $\geq 10$, Supplementary Table 1 and Supplementary Figure 2), whereas out of 395 differentially expressed phosphorylated proteins, 131 were mapped to six highly significant networks (score $\geq 10$, Supplementary Table 2 and Supplementary Figure 3). Networks were scored for likelihood of finding focus gene(s) in a given network. Biological relationship between two nodes was represented as an edge (line). Node color intensity indicated up-regulation (red) or down-regulation (green) degree. These networks demonstrated functional protein groups that are associated with multiple functions, such as cell death and survival, cellular assembly and organization, cellular growth and proliferation, cell cycle, cell morphology, and cellular movement, suggesting that ephrin-B2 is involved in multiple cellular functions.

\section{Results of in vitro cytological experiments}

Proteomic analysis indicated that ephrin-B2 promoted HUVECs proliferation, survival, migration, and cell cycle. To verify these effects, cytological experiments were performed in vitro.

\section{Ephrin-B2 promoted HUVECs proliferation}

Cell Counting Kit-8 (CCK-8) assay showed that ephrin-B2 significantly promoted endothelial cell proliferation at concentration of 0.3 or $1 \mu \mathrm{g} / \mathrm{mL}$ (Figure
4A). Higher concentration allows faster cell growth, suggesting that ephrin-B2 enhanced HUVEC proliferation in dose-dependent manner. Cell cycle detection showed that $\mathrm{G} 0 / \mathrm{G} 1$ phase cell ratio was significantly reduced after ephrin-B2 treatment, whereas S phase cell proportion was elevated (Figure 4B). Western blot results further indicated that expression levels of c-Myc and nucleophosmin (NPM), which promote cell proliferation, increased after ephrin-B2 treatment (Figure 4C and 4D).

\section{Ephrin-B2 promoted HUVECs migration}

Angiogenesis is mainly involved in endothelial cell migration and proliferation. Proteomic analysis indicated that ephrin-B2 can promote endothelial cell movement and migration. Wound healing experiment and Transwell assay were performed to confirm above results. Wound healing experiments showed that migration distance increased with ephrin-B2 concentration compared with that of the control group (Figure 5A). This result indicated dose-dependent enhancement of the effect of ephrin-B2 on HUVEC migration. Transwell experiment showed that ephrin-B2 promoted endothelial cell migration at concentrations from $0.1 \mu \mathrm{g} / \mathrm{mL}$ to $1 \mu \mathrm{g} / \mathrm{mL}$ and enhanced effect peaked at $1 \mu \mathrm{g} / \mathrm{mL}$. However, number of migrated cells treated with $3 \mu \mathrm{g} / \mathrm{mL}$ ephrin-B2 did not significantly change compared with that of the control group (Figure $5 \mathrm{~B})$. This result indicated that the effect of ephrin-B2 on endothelial cell migration was dose-dependent at $0-1 \mu \mathrm{g} /$ $\mathrm{mL}$, and that enhanced effect disappeared when ephrin-B2 concentration reached $3 \mu \mathrm{g} / \mathrm{mL}$. Western blot results further indicated that pro-migration protein Twist and matrix metallopeptidase 9 (MMP9) expression increased after treatment with $1 \mu \mathrm{g} / \mathrm{mL}$ ephrin-B2. Twist expression increased immediately to a high level $(5 \mathrm{~min})$ and then declined, whereas no significant increase was observed for MMP9 until $2 \mathrm{~h}$ after ephrin-B2 incubation (Figure 5C and 5D).

\section{Ephrin-B2 inhibited apoptosis in HUVECs}

To detect cell apoptosis protection by ephrin-B2, $\mathrm{H}_{2} \mathrm{O}_{2}$ was used as inducer for apoptosis. As shown in Figure 6A, HUVECs survival ratio declined significantly 


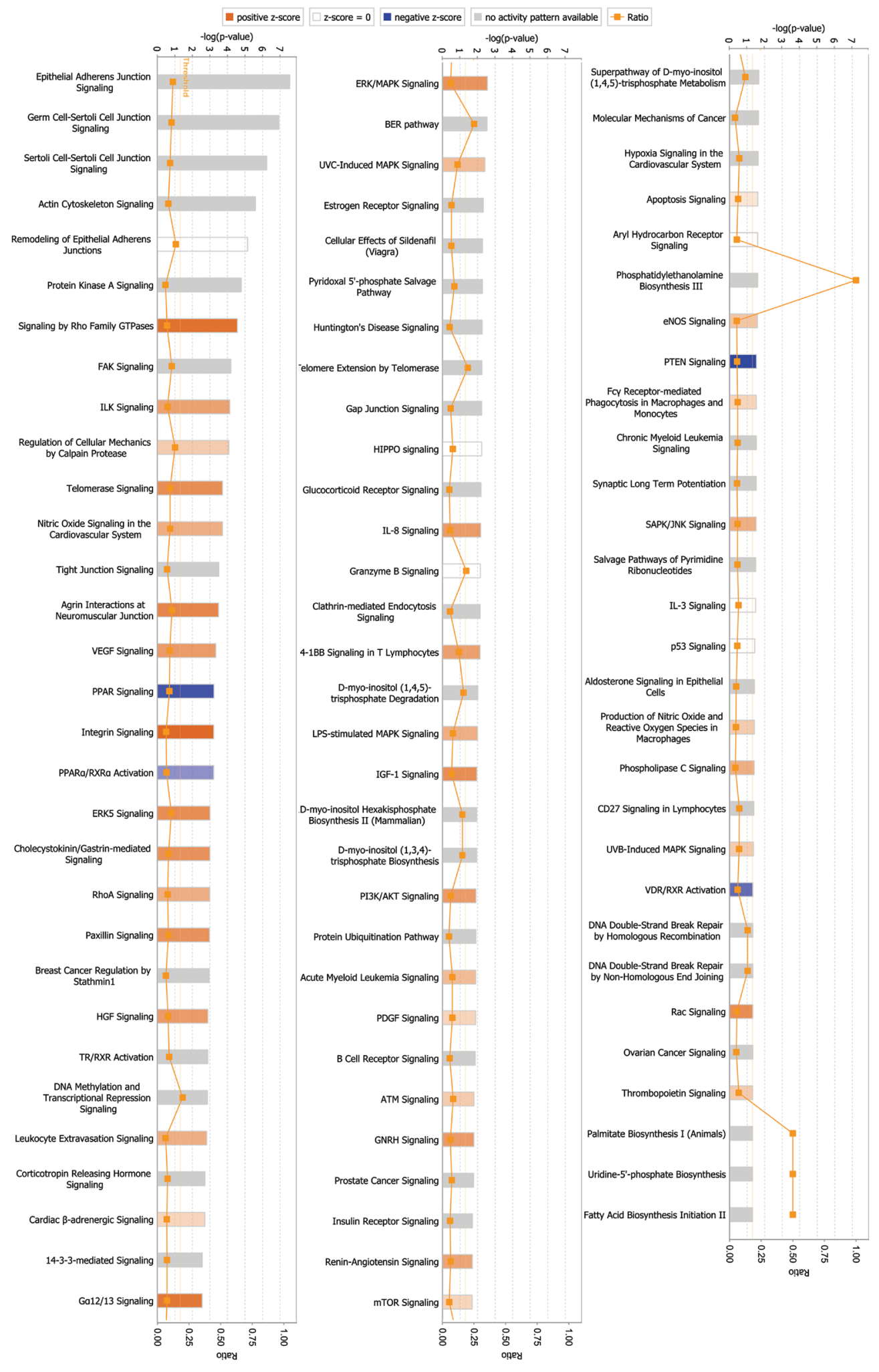

Figure 3: Signaling pathways associated with differentially expressed phosphorylated proteins. Signaling by Rho GTPases exhibited the highest correlation among signaling pathways. $p$-value was calculated using right-tailed Fisher's exact test to assess association level. $p<0.05$ or $-\log (p$-value $)>1.3$ (the main axis or bar chart) signifies significant association. Threshold line indicating significant level was set at $p=0.05$, or $-\log (p$-value $)=1.3$ means. Z-score was calculated per expression level (up or down) of corresponding molecules in experiments and expected expression value (up or down) in pathways. Z-scores $\geq 2$ or $\leq-2$ indicate that signaling pathway was statistically and significantly activated (colored in yellow) or inhibited (colored in blue). The ratio denotes proportion of differently expressed genes in total signaling pathway genes. This ratio was provided as reference for significance assessment. 
Table 4: Significant canonical pathways associated with differentially expressed phosphorylated proteins

\begin{tabular}{lccc}
\hline Ingenuity Canonical Pathways & $-\log (\boldsymbol{p}$-value $)$ & Ratio & z-score \\
\hline Integrin Signaling & $3.22 \mathrm{E} 00$ & $6.93 \mathrm{E}-02$ & 3.464 \\
Signaling by Rho Family GTPases & $4.56 \mathrm{E} 00$ & $7.69 \mathrm{E}-02$ & 3.153 \\
Ga12/13 Signaling & $2.56 \mathrm{E} 00$ & $7.69 \mathrm{E}-02$ & 3.000 \\
ERK5 Signaling & $3.01 \mathrm{E} 00$ & $1.11 \mathrm{E}-01$ & 2.449 \\
IGF-1 Signaling & $1.96 \mathrm{E} 00$ & $7.22 \mathrm{E}-02$ & 2.449 \\
Rac Signaling & $1.33 \mathrm{E} 00$ & $5.77 \mathrm{E}-02$ & 2.449 \\
ERK/MAPK Signaling & $2.56 \mathrm{E} 00$ & $6.42 \mathrm{E}-02$ & 2.309 \\
VEGF Signaling & $3.33 \mathrm{E} 00$ & $9.89 \mathrm{E}-02$ & 2.121 \\
HGF Signaling & $2.88 \mathrm{E} 00$ & $8.57 \mathrm{E}-02$ & 2.121 \\
PI3K/AKT Signaling & $1.91 \mathrm{E} 00$ & $6.5 \mathrm{E}-02$ & 2.121 \\
IL-8 Signaling & $2.18 \mathrm{E} 00$ & $6.01 \mathrm{E}-02$ & 2.111 \\
\hline
\end{tabular}

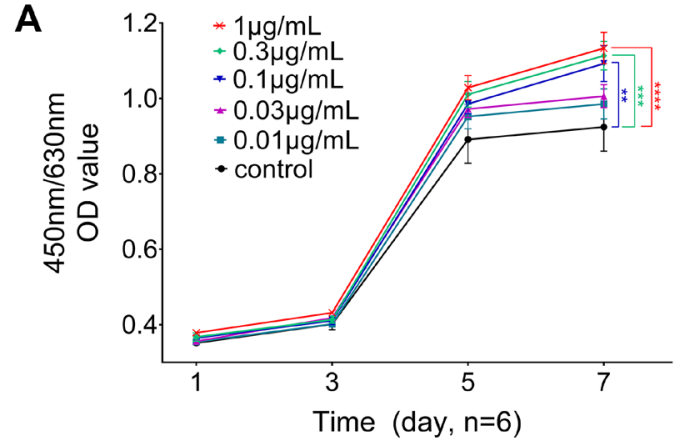

C
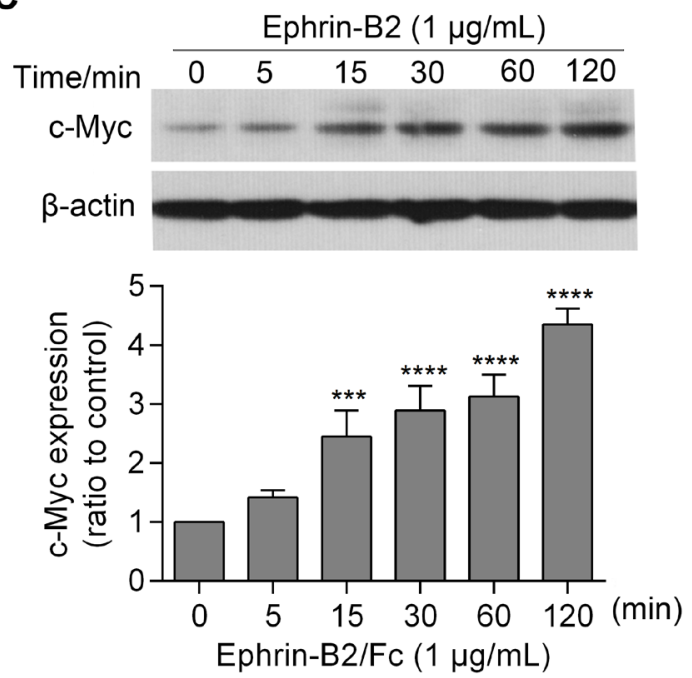

B

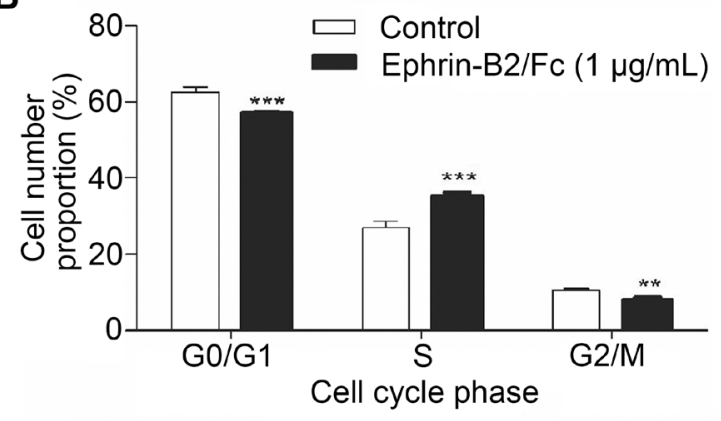

D
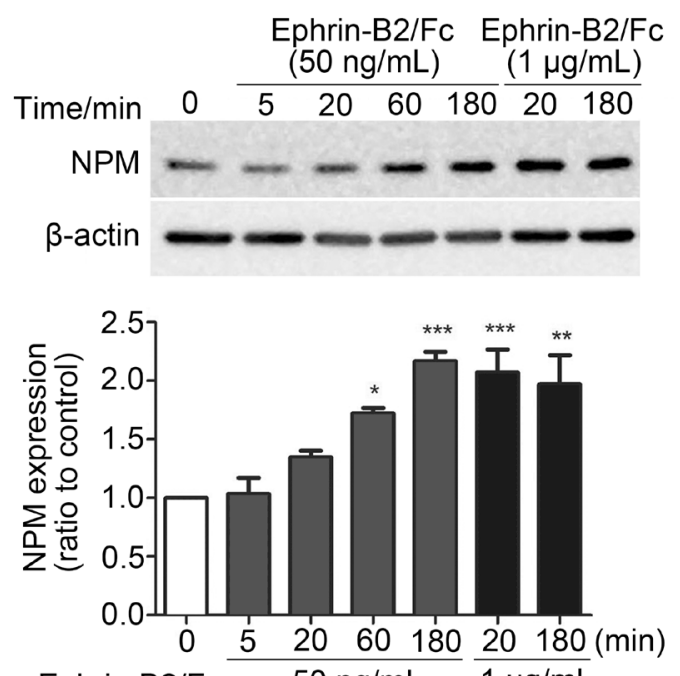

Ephrin-B2/Fc $50 \mathrm{ng} / \mathrm{mL} \quad 1 \mu \mathrm{g} / \mathrm{mL}$

Figure 4: Ephrin-B2 promotes HUVECs proliferation. (A) Ephrin-B2 significantly promoted endothelial cell proliferation at concentration of 0.3 or $1 \mu \mathrm{g} / \mathrm{mL}$. Cell viability was detected using CCK-8 assay [mean $\pm \mathrm{SEM}, \mathrm{n}=6,{ }^{* *} p<0.01,{ }^{* * *} p<0.001,{ }^{* * * *} p<$ 0.0001, by analysis of variance (ANOVA) and Dunnett's multiple comparison test]. (B) Effect of ephrin-B2 on cell cycle of HUVECs. Cells were treated with $1 \mu \mathrm{g} / \mathrm{mL}$ ephrin-B2/Fc for $24 \mathrm{~h}$ and then analyzed using cytometry $(\mathrm{n}=3$, mean $\pm \mathrm{SEM}, * * p<0.01, * * * p<0.001, * * * * p$ $<0.0001$ vs. control using Student's t-test). (C and D) Western blot showed the effect of ephrin-B2 on c-Myc and NPM protein expression levels. Bands were quantified using Quantity One software (mean $\pm \mathrm{SEM}$; $\mathrm{ns},{ }^{*} p<0.05,{ }^{*} p<0.01,{ }^{*} * p<0.001$, and $* * * * p<0.0001 \mathrm{vs}$. control using ANOVA and Dunnett's multiple comparison test). 
A

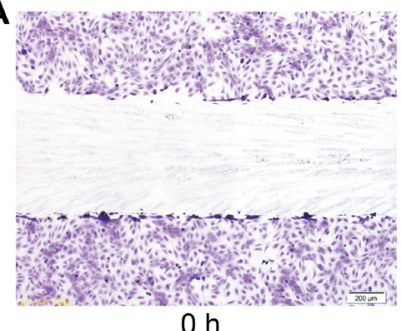

$0 \mathrm{~h}$

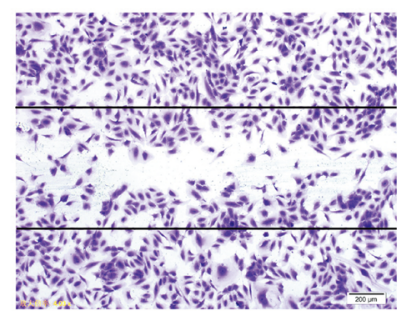

$0.3 \mu \mathrm{g} / \mathrm{mL}$ ephrin-B2/Fc (24 h)

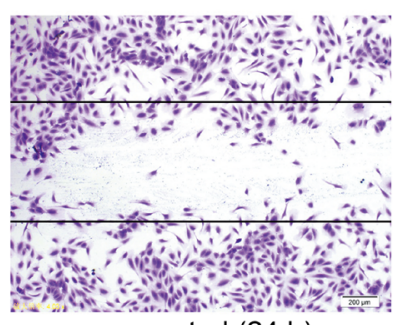

control $(24 \mathrm{~h})$

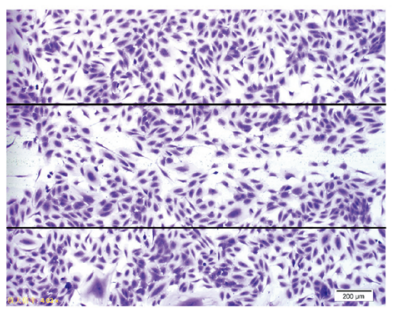

$1 \mu \mathrm{g} / \mathrm{mL}$ ephrin-B2/Fc (24 h)

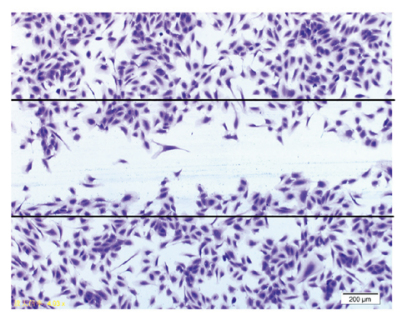

$0.1 \mu \mathrm{g} / \mathrm{mL}$ ephrin-B2/Fc (24 h)

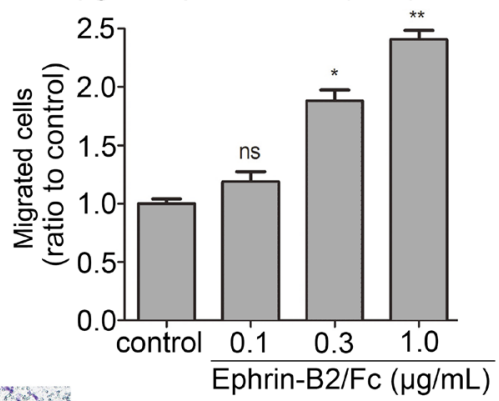

B

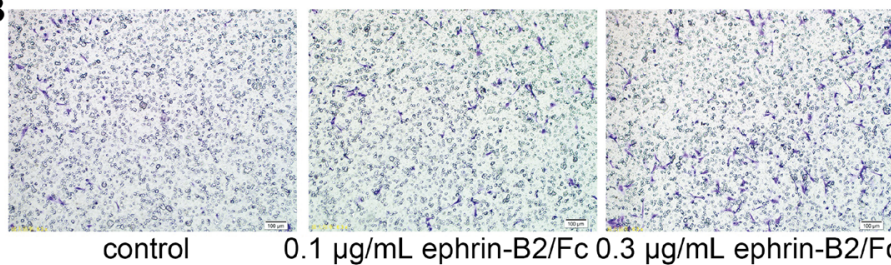

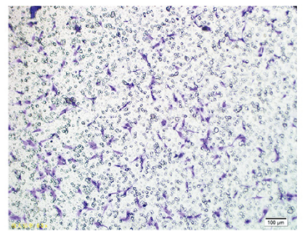

$1 \mu \mathrm{g} / \mathrm{mL}$ ephrin-B2/Fc

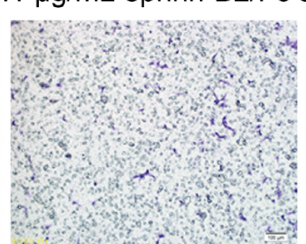

$3 \mu \mathrm{g} / \mathrm{mL}$ ephrin-B2/Fc

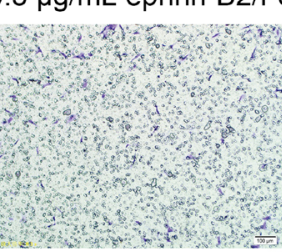

$1 \mu \mathrm{g} / \mathrm{mL} \lg G$

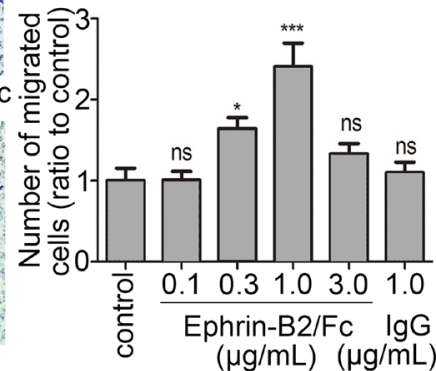

$(\mu \mathrm{g} / \mathrm{mL})(\mu \mathrm{g} / \mathrm{mL})$

C

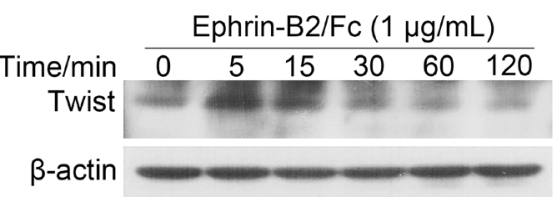

D
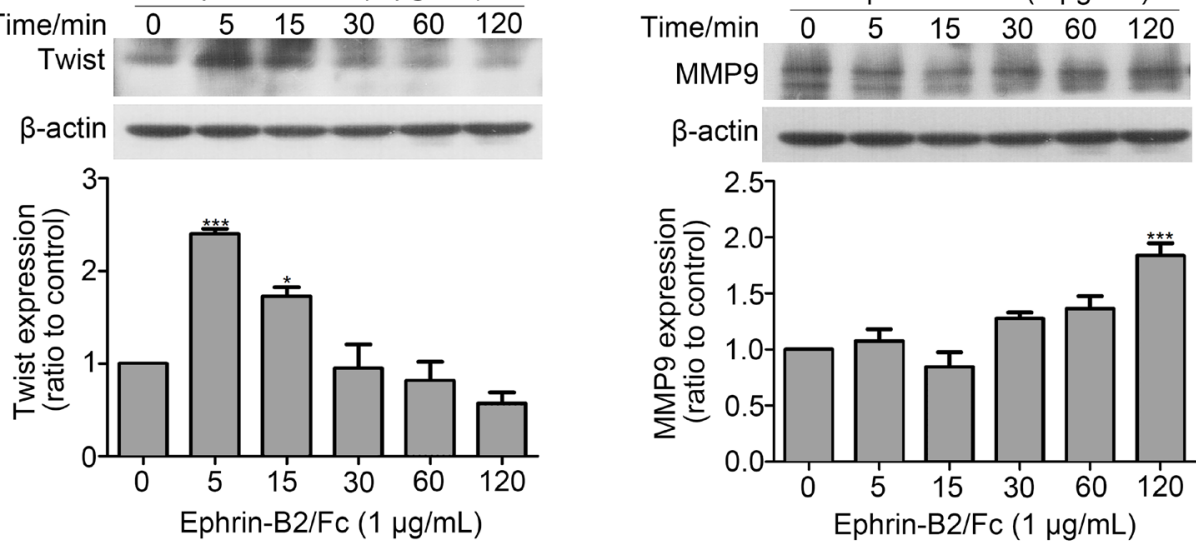

Figure 5: Ephrin-B2 promotes HUVEC migration. (A) Wound-healing assay. Consistently shaped wounds were created after $12 \mathrm{~h}$ of serum starvation. Cells were cultured for $24 \mathrm{~h}$ in serum-free medium containing different ephrin-B2/Fc concentrations or PBS, fixed by $4 \%$ paraformaldehyde, and stained using crystal violet. Images were captured under the microscope (100 times magnification), and in each well, six different scraped areas were randomly selected and analyzed. Cells treated by 0.3 or $1 \mu \mathrm{g} / \mathrm{mL}$ ephrin-B2 showed higher migration ratio ( $\mathrm{n}=3$, mean $\pm \mathrm{SEM} ; \mathrm{ns},{ }^{*} p<0.05,{ }^{* *} p<0.01$ vs. control using ANOVA and Dunnett's multiple comparison test). (B) Transwell assay. A total of 35,000 cells were cultured on the upper chamber using serum-free medium containing different ephrin-B2/Fc concentrations $(0$, $0.1,0.3,1$, and $3 \mu \mathrm{g} / \mathrm{mL}$ ), which were poured onto the bottom chamber as migration stimulator. Six hours later, migrated cells were fixed, stained, photographed, and then counted according to normal methods. Cells dose-dependently migrated under low concentrations $(\mathrm{n}=3$, mean \pm SEM; ns, ${ }^{*} p<0.05$ and ${ }^{* * *} p<0.001$ vs. control using ANOVA and Dunnett's multiple comparison test). (C and D) Western blot showed the effects of ephrin-B2 on Twist and MMP9 protein expression levels. Bands were quantified using Quantity One software (mean \pm SEM; ns, ${ }^{*} p<0.05$ and ${ }^{* * *} p<0.001$ vs. control using ANOVA and Dunnett's multiple comparison test). 
when $\mathrm{H}_{2} \mathrm{O}_{2}$ concentration reached $0.3 \mathrm{mmol} / \mathrm{L}$. After ephrin-B2 treatment for prior protection, survival ratio showed dose-dependent improvement (Figure 6B). Western blot analysis showed increased level of antiapoptotic protein $\mathrm{Bcl}-2$ expression after ephrin-B2 treatment (Figure 6C), whereas cleaved caspase 3 gradually decreased by $1 \mu \mathrm{g} / \mathrm{mL}$ ephrin-B2 (Figure 6D).

\section{Ephrin-B2 activated some HUVEC signaling pathways}

As shown in Figure 3, many signaling pathways were activated or inactivated by ephrin-B2. However, verifying all changes was difficult. We attempted to detect the effect of ephrin-B2 on PI3K-Akt, VEGF, and P38

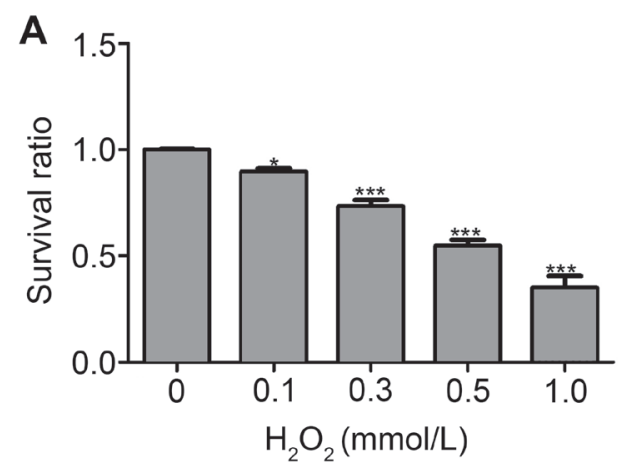

C
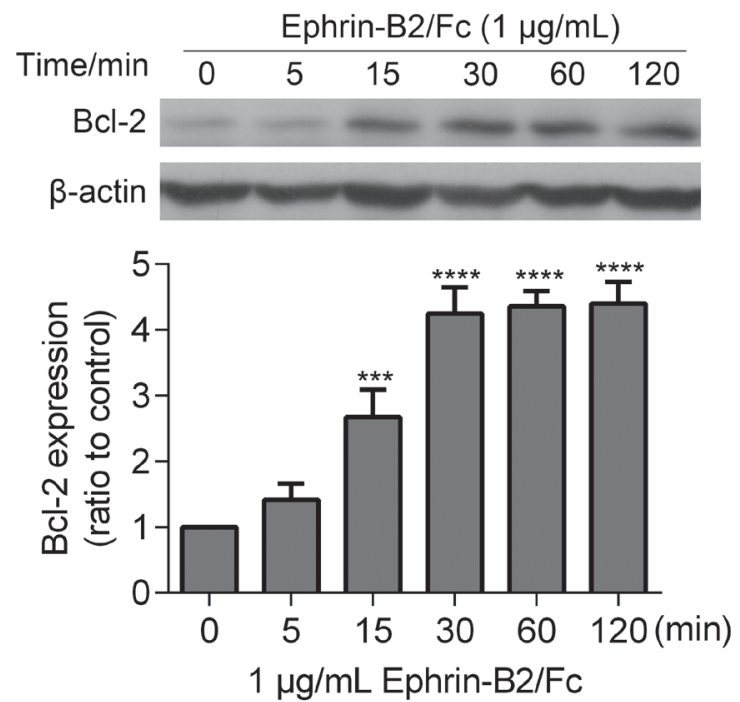

signaling pathways, which have close relationship with cell proliferation, migration, and survival, respectively. As shown in Figure 7A, pAkt (Thr308) expression was increased by ephrin-B2. eNOS is a PI3K-Akt downstream factor; its expression level increased following $\mathrm{Akt}$ activation (Figure 7B). Ephrin-B2 treatment significantly increased pP38 (Thr180/182) level, demonstrating activation of P38 signaling pathway (Figure 7C).

\section{DISCUSSION}

Endothelial cell proliferation and migration are two major events during angiogenesis [29]. Previous studies on
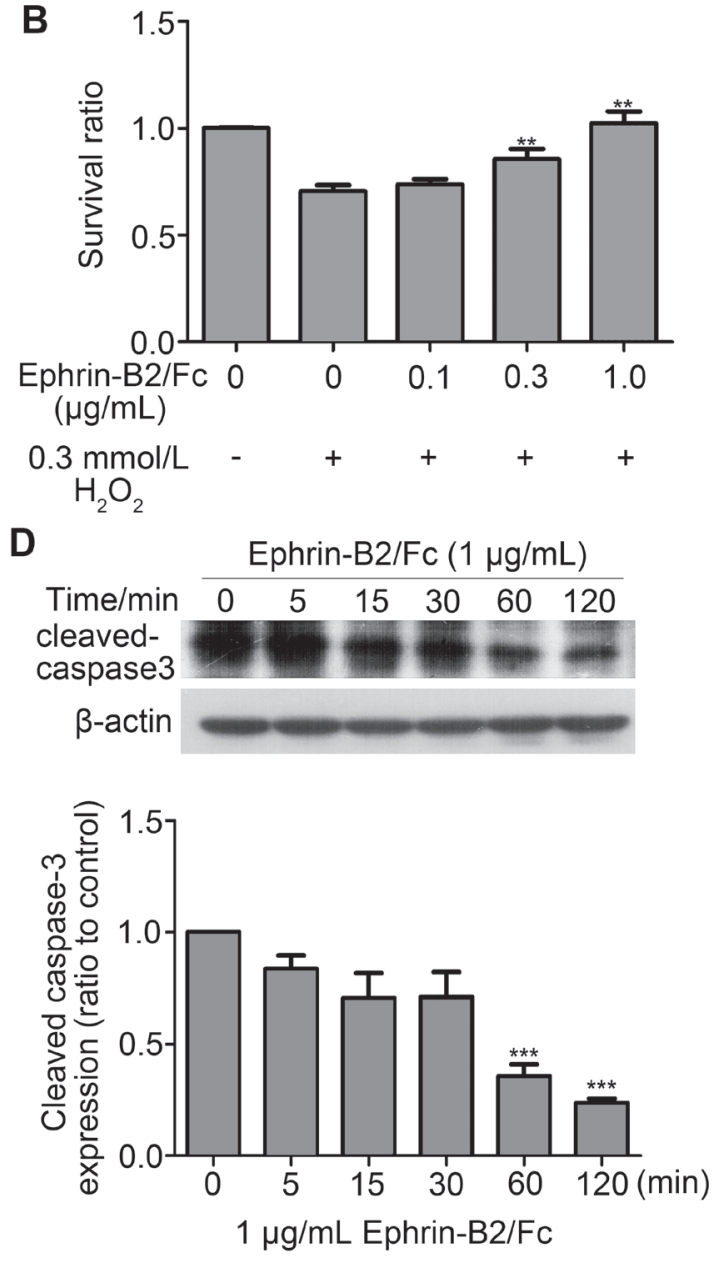

Figure 6: Ephrin-B2 inhibits HUVEC apoptosis. (A) Cell apoptosis assay by CCK-8. Cell apoptosis was induced $4 \mathrm{~h}$ after incubation with different concentrations of $\mathrm{H}_{2} \mathrm{O}_{2}$. Cell survival ratios were then tested at OD450 nm. Relatively significant level of apoptosis was observed at concentration of $0.3 \mathrm{mmol} / \mathrm{L}\left(\mathrm{n}=3\right.$, mean $\pm \mathrm{SEM}$; $\mathrm{ns},{ }^{*} p<0.05,{ }^{* *} p<0.001 \mathrm{vs}$. control using ANOVA and Dunnett's multiple comparison test). (B) Different concentrations of ephrin-B2/Fc $(0.1,0.3$, and $1 \mu \mathrm{g} / \mathrm{mL})$ contribute to protecting HUVECs from apoptosis, which is induced by $\mathrm{H}_{2} \mathrm{O}_{2}(0.3 \mathrm{mmol} / \mathrm{L})$. Cells were cultured in serum-free medium containing different concentrations of ephrin-B2/Fc or PBS for $2 \mathrm{~h}$ then incubated with $\mathrm{H}_{2} \mathrm{O}_{2}$ for $4 \mathrm{~h}$. Cell survival ratios were also tested on OD450 nm. Cells treated by $1 \mu \mathrm{g} / \mathrm{mL}$ ephrin-B2 showed higher survival ratio $(\mathrm{n}=3$, mean $\pm \mathrm{SEM}$; $\mathrm{ns}, * * p<0.01$ vs. control using ANOVA and Dunnett's multiple comparison test). (C-D) Western blot showed the effects of ephrin-B2 on Bcl-2 and cleaved caspase 3 protein expression levels. Bands were quantified using Quantity One software (mean $\pm \mathrm{SEM}$; $\mathrm{ns},{ }^{* *} p<0.01,{ }^{* * *} p<0.001$ and $* * * * \mathrm{p}<0.0001 \mathrm{vs}$. control using ANOVA and Dunnett's multiple comparison test). 
the role of ephrin-B2 in endothelial cells mainly focused on cell growth, proliferation, and migration $[25,30]$. In the present study, proteomic analysis revealed that ephrin-B2 significantly activated multiple signaling pathways related to cell proliferation, survival, and migration and suppressed apoptosis and nuclear factor erythroid 2-related factor 2 (NRF2)-mediated oxidative stress response. Cytological experiments further confirmed that ephrin-B2 stimulated proliferation, caused HUVECs dose-dependent migration, increased anti-apoptotic Bcl-2 expression, proproliferation proteins c-Myc and NPM, and pro-migration proteins Twist and MMP9, activated Akt/eNOS and P38 signaling pathways, and inhibited activation of caspase 3 .

Different studies reported contradicting results regarding the effects of ephrin-B2 on endothelial cells.
Some evidence indicated that by interfering VEGF and Ang-1 signal transmissions, ephrin-B2 inhibits proliferation, migration, and vascular budding of endothelial cells, where EphB4 receptors are located, thereby inhibiting angiogenesis [28, 30, 31]. By contrast, other studies showed that ephrin-B2 promotes proliferation and migration by activating EphB4 receptors [25, 32, 33]. This discrepancy may be explained by different experimental models used or ephrin-B2 concentration variations in those studies. In the current study, as exhibited in our cytological experiments, potency of promoting migration by ephrin-B2 was strong when concentration was set to 0.3 and $1 \mu \mathrm{g} / \mathrm{mL}$, which are lower than the dosage used in previous studies. Endothelial progenitor cells were treated with $3 \mu \mathrm{g} / \mathrm{ml}$ Eph-B2-Fc in Foubert's
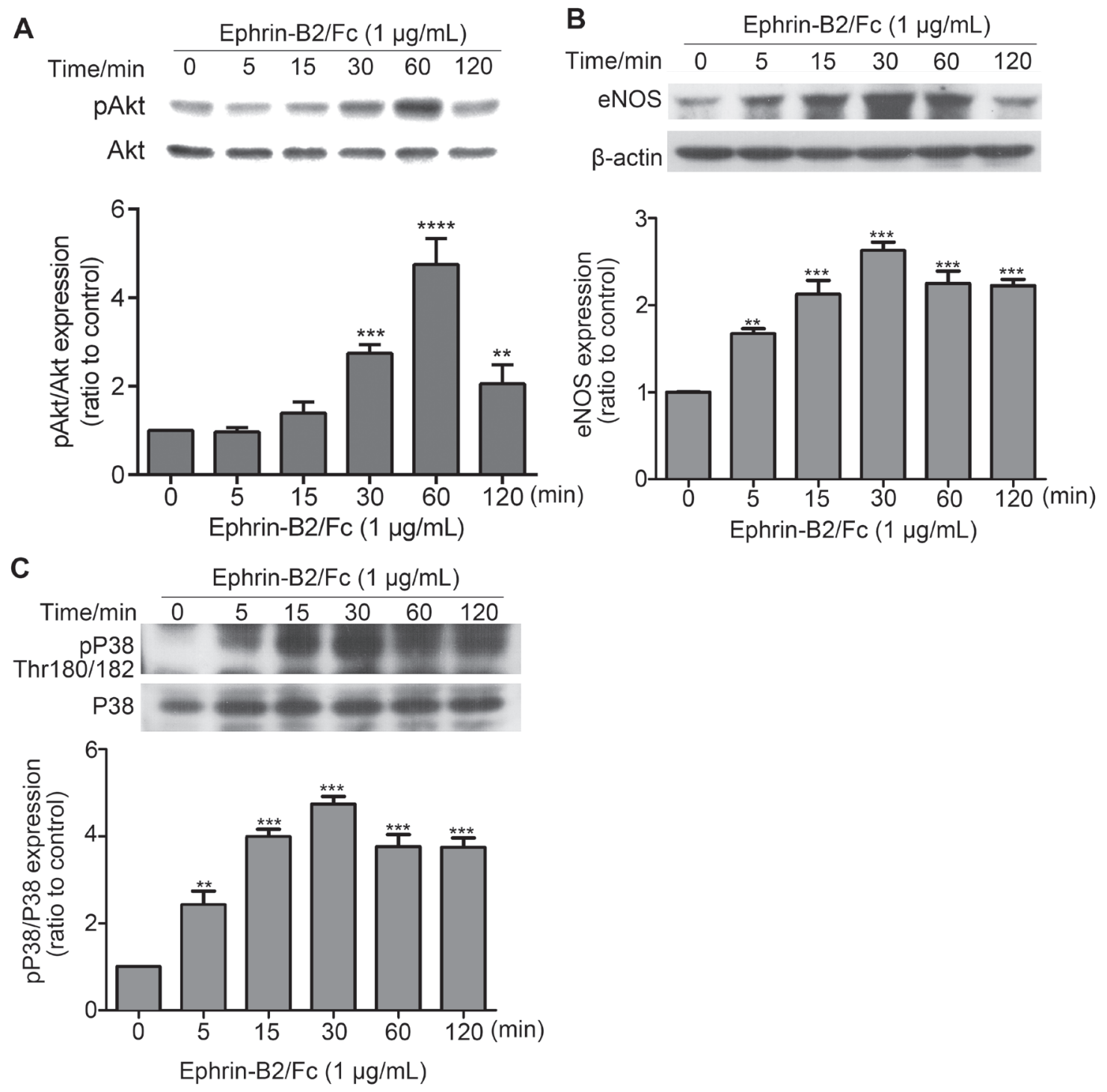

Figure 7: Effects of ephrin-B2 on signaling pathways in HUVECs. HUVECs were treated with $1 \mu \mathrm{g} / \mathrm{mL}$ ephrin-B2 for 5, 15 , and $30 \mathrm{~min}$ and for 1 and $2 \mathrm{~h}$. Expression levels of pAkt (A), eNOS (B), and pP38 (C) were detected by Western blot. Intensity of each band was quantified by Quantity One software (mean \pm SEM; ns, ${ }^{* *} p<0.01$ and $* * * p<0.001, * * * * p<0.0001$, vs. control using ANOVA and Dunnett's multiple comparison test). $\beta$-actin was used as internal control. 
study [34]. In Mansson-Broberg's study [35], 0.5, 5, and $10 \mu \mathrm{g} / \mathrm{mL}$ Eph-B2 were used in human adult endothelial cell cultures, and a single dose of $20 \mu \mathrm{g}$ ephrinB2-Fc was used for C57BL/6 mice weighing $25 \mathrm{~g}$. However, enhancement of migration by $3 \mu \mathrm{g} / \mathrm{mL}$ ephrin-B2 was not significant in the current study. Ephrin-B2 from different sources may possess different activity, possibly resulting in significant differences in effective concentration of ephrin-B2. However, variable results in previous reports and our study most possibly reflect the dependence of ephrin-B2 effects on experimental models or ephrin-B2 concentration used.

Previous studies explored specific signaling pathways to explain the effects of ephrin-B2 on cells. Such research is often segmentary, and results may not reflect all changes induced by ephrin-B2. By quantitatively analyzing alteration in global and phosphorylated protein expression profiles of HUVECs, the current study systematically and comprehensively uncovered cellular function changes and associated signaling pathways mediated by ephrin-B2. Previous studies on ephrin-B2 did not report alterations in these signaling pathways or their cellular functions. These alterations can provide clues to future research on ephrin-B2 mechanism. For example, inactivated signaling pathways including NRF2-mediated oxidative stress response, peroxisome proliferator activated-receptor (PPAR) signaling, and PPAR $\alpha /$ retinoid $X$ receptor $\alpha(R X R \alpha)$ activation, were all related to oxidative stress (blue bar in Figure 2 and 3); though not meeting threshold z-score, these results may be a clue to explain Foubert's finding [34], which indicated that in wound healing, Eph-B2 improves beneficial effects of endothelial progenitor cell in physiological and irradiated conditions only when in association with antioxidant treatment. Mansson-Broberg's study [35] also showed that in hypoxic environment, proliferation rate of human adult endothelial cells is significantly lower in ambient air, and adding ephrin-B2 $(0.05,0.5,5$, and $10 \mu \mathrm{g} /$ $\mathrm{mL})$ increases proliferation rate $(\mathrm{p}<0.10)$. These previous studies and ours revealed that inactivated oxidative stress related signaling pathways possibly modulate effects of ephrin-B2. The link between these phenomena is worth further study.

Here, we also observed an alteration on signaling pathway of Fc gamma receptor-mediated phagocytosis in macrophages and monocytes (Figure 2 and Figure 3). Although the z-score indicated by IPA is no of significance (1.342 in Figure 2 and 0.816 in Figure 3), there is still a possibility that part of response we detected may be due to $\mathrm{Fc}$ gamma receptor stimulation, since ephrin-B2/Fc was used as the stimulant. However, we do not think Fc gamma receptor cause too much disturbance to our conclusion. Recombinant protein ephrin-B2/Fc has been used by many researchers for studying the function of ephrin-B2 [3638]. In fact, since half-life of $\mathrm{Fc}$ recombinant proteins is much longer than their original form, Fc has been widely used to produce $\mathrm{Fc}$ fusion proteins in pharmaceutical field [39]. Moreover, the only Fc receptor expressed in endothelial cells is the neonatal $\mathrm{Fc}$ receptor ( $\mathrm{FcRn})$ [40]. Its main function in endothelial cells is to protect IgG or fusion proteins from being metabolized [41]. Therefore, we think $\mathrm{Fc}$ is unlikely to cause any remarkable response in HUVECs.

In the present study, through a series of proteomic and cytological experiments, we proved that ephrin-B2 exerts dose-dependent effects on HUVEC proliferation and migration and suppresses cell apoptosis. Considering its positive roles in promoting endothelial cell proliferation and migration, ephrin-B2 is expected to be a therapeutic candidate in angiogenesis-related diseases and tumor.

As a reversible and transient modification, phosphorylation is mostly studied at the beginning stage of stimulation. In this study, we choose to perform analyzing events on changes of global and phosphorylated proteins at the same stage $(15 \mathrm{~h}$ after stimulation), to make our conclusions more persuasive. We think that phosphorylation must play a key role in both the initial signal transduction and subsequent signaling pathway and protein function regulation. Phosphorylation is the most ubiquitous post-translational modification (PTM) a protein experiences throughout its lifetime. It serves to modify protein function by altering protein stability, cellular location, substrate affinity, complex formation, and activity [42]. Therefore, not only the expression level of proteins but also the phosphorylation level of related proteins is changed by ephrin-B2 at $15 \mathrm{~h}$. In fact, our results demonstrated a large number of phosphorylated proteins were changed at $15 \mathrm{~h}$ (1377 phosphorylated sites of 395 proteins). And many biofunctions revealed by proteomics analysis of global and phosphorylated proteins were consistent (Table 1 and 2).

Notably, this current study examined only the effects of ephrin-B2 on HUVECs in vitro. Though results of proteomic analysis agree with results of cell-level assays, the present study cannot provide final answers to existing open questions or solve previous controversies. Further experiment in vivo should be carried out to clarify functions and mechanisms of ephrin-B2 on endothelial cell proliferation and migration.

\section{MATERIALS AND METHODS}

\section{Chemical}

Ephrin-B2/Fc was purchased from R\&D Systems (USA). All antibodies were purchased from Cell Signaling Technology, Inc. SILAC kits were purchased from Thermo Fisher Scientific, Inc. (USA). Other chemical compounds were purchased from Sigma (USA). 


\section{HUVEC isolation and culture}

All research involving human subjects were conducted in agreement with the Declaration of Helsinki. Studies involving HUVECs were approved by the Ethical Review Board of the Medical College of Xiamen University, and an informed consent was signed by suppliers. Freshly isolated umbilical cords were obtained from affiliated Zhongshan Hospital of Xiamen University.

Umbilical veins were washed thrice with cold sterile PBS (Gibco). Both ends of umbilical veins were bound and filled with $0.05 \%$ trypsin-ethylenediaminetetraacetic acid (EDTA) buffer (Gibco). After incubation for $10 \mathrm{~min}$ at $37^{\circ} \mathrm{C}$, endothelial cells were washed with Dulbecco's modified Eagle's medium (DMEM) containing 20\% fetal bovine serum (FBS, Gibco) and subsequently centrifuged at $400 \times \mathrm{g}$ for $10 \mathrm{~min}$ at $4{ }^{\circ} \mathrm{C}$. Separated cells were cultured in DMEM containing $20 \%$ FBS, and adherent cells were preserved for passage in accordance with conventional method. In the present study, all cells used were cultured for four to six passages.

\section{SILAC labeling and cell treatment}

Isolated HUVECs were cultured in DMEM medium containing $10 \% \mathrm{FBS}$ at $37^{\circ} \mathrm{C}$ with $95 \%$ air and $5 \% \mathrm{CO}_{2}$. Cells were labeled with "heavy" SILAC media (Thermo) containing $0.1 \mathrm{~g} / \mathrm{L}^{13} \mathrm{C}_{6}{ }^{15} \mathrm{~N}_{2} \mathrm{~L}-\mathrm{Ly}$ sine- $2 \mathrm{HCl}$ and $0.1 \mathrm{~g} / \mathrm{L}{ }^{13} \mathrm{C}_{6}{ }^{15} \mathrm{~N}_{4} \mathrm{~L}$-Arginine-HCl or "light" SILAC media (Thermo) containing $0.1 \mathrm{~g} / \mathrm{L}$ L-Lysine- $2 \mathrm{HCl}$ and $0.1 \mathrm{~g} / \mathrm{L}$ L-Arginine-HCl. After five times of passage and $80 \%$ confluence, cells labeled with light amino acid were treated with $1 \mu \mathrm{g} / \mathrm{mL}$ ephrin-B2/Fc for $15 \mathrm{~h}$, whereas cells labeled with heavy amino acid were treated with PBS for $15 \mathrm{~h}$.

\section{Peptide preparation}

Cells were lysed in urea lysis buffer (8 $\mathrm{M}$ urea in 0.1 $\mathrm{M}$ Tris- $\mathrm{HCl}, \mathrm{pH}$ 8.5) containing protease and phosphatase inhibitors. Protein concentration was determined by Bradford assay. Equal amounts (125 $\mu \mathrm{g})$ of light or heavyisotope-labeled proteins were mixed and precipitated in pre-cooled acetone $\left(-20^{\circ} \mathrm{C}\right)$ for at least $1 \mathrm{~h}$. Depending on different applications, precipitated protein was handled through the following steps:

\section{Differentially expressed global protein sample}

Precipitated proteins were dissolved in radioimmunoprecipitation assay (RIPA) lysis buffer and separated by sodium dodecyl sulfate polyacrylamide gel electrophoresis (SDS-PAGE) after centrifugation at 3,000 $\times \mathrm{g}$ for $10 \mathrm{~min}$. Gel was equally cut off into nine pieces on the basis of protein molecular weight. Each gel piece was reduced using DL-Dithiothreitol (DTT), alkalized with iodoacetamide (IAM), and in-gel digested with modified trypsin (Promega). Peptides were extracted, desalted with SepPak C18 (Waters, USA), and stored at $-80{ }^{\circ} \mathrm{C}$.

\section{Differentially expressed phosphorylated protein sample}

After centrifugation at $3,000 \times \mathrm{g}$ for $10 \mathrm{~min}$, precipitated proteins were dissolved in $200 \mu \mathrm{L}$ of urea lysis buffer containing $0.05 \mathrm{M}$ DTT for $45 \mathrm{~min}$ and then mixed with $300 \mu \mathrm{L}$ of iodoacetamide (IAM) solution $(0.05$ M IAM in urea lysis buffer). Mixture was incubated in the dark for $20 \mathrm{~min}$ and centrifuged in an ultrafiltration tube (Millipore, $30 \mathrm{~K}$ ) at $14,000 \times \mathrm{g}$ for $15 \mathrm{~min}$. Up to $300 \mu \mathrm{L}$ of ammonium bicarbonate (ABC) solution $(0.05 \mathrm{M}$ $\mathrm{NH}_{4} \mathrm{HCO}_{3}$ in $\mathrm{H}_{2} \mathrm{O}$ ) was added into ultrafiltration tube and then subsequently centrifuged at $14,000 \times \mathrm{g}$ for $15 \mathrm{~min}$. This step was repeated twice. Trypsin (1:50) was added to protein samples, and resulting mixture was added to $100 \mu \mathrm{L}$ of $\mathrm{ABC}$ solution. The sample was vibrated and incubated at $37{ }^{\circ} \mathrm{C}$ for $4-18 \mathrm{~h}$. Up to $50 \mu \mathrm{L}$ of $\mathrm{H}_{2} \mathrm{O}$ was added, and the tube was centrifuged in a new collector at 4 ${ }^{\circ} \mathrm{C}$ for $15 \mathrm{~min}$. This step was repeated, and liquid effluents containing peptides were combined. Subsequently, 1\% formic acid (final concentration) was added to effluents, which were desalted with SepPak C18. Peptides were dried and stored at -20 or $-80{ }^{\circ} \mathrm{C}$. Phosphorylated peptide enrichment was performed using titanium dioxide affinity chromatography for phosphorylated protein analysis.

\section{Peptide detection and data analysis}

Dried peptides were dissolved in $0.1 \%$ formic acid $/ 2 \%$ acetonitrile and analyzed on AB Sciex Triple TOF 5600 mass spectrometer (MS) system. Acquired raw data files (.wiff) were searched using Protein Pilot software V.4.2 (AB Sciex, USA) against protein sequence database. Finally, obtained data were uploaded to IPA (https://www. qiagenbioinformatics.com/products/ingenuity-pathwayanalysis/) for bioinformatics analysis. As SILAC is a highly accurate quantitative method, cutoff for fold change was set to 1.50 , and $p$-value was less than 0.05 . This study employed global functional analyses, network analyses, and canonical pathway analyses.

For differentially expressed global protein samples, peptide sample of each gel piece was individually analyzed on MS. After searching against protein sequence database, nine sets of data were merged. Above experimental process was repeated thrice; data were merged and then uploaded to IPA for analysis.

\section{Cell proliferation assay}

HUVECs were seeded in 96-well plate at a density of 3,000 cells per well. After overnight serum starvation, cells were incubated in DMEM containing 2\% FBS and different ephrin-B2/Fc concentrations at $37{ }^{\circ} \mathrm{C}$ and $5 \% \mathrm{CO}_{2}$. Cell proliferation was measured using CCK-8 following manufacturer's instructions at indicated times 
$(1,3,5$, and 7 days). PBS was used in control group. Eight repetitive wells were set for each group.

\section{Cell cycle analysis}

After $24 \mathrm{~h}$ of serum starvation, HUVECs were cultured in DMEM containing 2\% FBS and $1 \mu \mathrm{g} / \mathrm{mL}$ ephrin-B2/Fc at $37^{\circ} \mathrm{C}$ for $24 \mathrm{~h}$. Cells were then harvested and fixed in $70 \%$ pre-cooled ethanol at $4{ }^{\circ} \mathrm{C}$. After incubation with $100 \mathrm{mg} / \mathrm{L} \mathrm{RNase} \mathrm{A}$ at $37^{\circ} \mathrm{C}$ for $30 \mathrm{~min}$, $50 \mathrm{mg} / \mathrm{L}$ propidium iodide was added into suspended cells in the dark for $30 \mathrm{~min}$ at room temperature. More than 10,000 cells in each sample were analyzed by flow cytometry (Bacton Dickson Co.), and data were analyzed using MultiCycle for Windows 32-bit software.

\section{Wound healing assay}

HUVECs were seeded on six-well plates and grown to $100 \%$ confluence. After $12 \mathrm{~h}$ of serum starvation, consistently shaped wounds were made using a sterile 200 $\mu \mathrm{L}$ pipette tip across bottom surfaces of each well, creating cell-free areas. Cultures were gently washed with PBS to remove loose cells. Cells were cultured in serum-free medium containing different ephrin-B2/Fc concentrations or PBS for $24 \mathrm{~h}$, fixed in $4 \%$ paraformaldehyde for $20 \mathrm{~min}$, and then stained with crystal violet for $30 \mathrm{~min}$ at room temperature. Cell images were captured under an optical microscope. Six different scraped areas of each well were randomly selected, and cell numbers were counted.

\section{Transwell migration assay}

Migration assay was performed using Transwell chambers $(8 \mu \mathrm{m}$ in pore size, Corning). A total of 400 $\mu \mathrm{L}$ serum-free DMEM containing different ephrin-B2/Fc concentrations was added to the lower chamber, whereas $3.5 \times 10^{4}$ cells in $200 \mu \mathrm{L}$ of DMEM were planted onto the upper chamber. Cells were cultured for $6 \mathrm{~h}$ at $37{ }^{\circ} \mathrm{C}$ under humidified $5 \% \mathrm{CO}_{2}$ atmosphere. Cells in upper chamber were tenderly removed using wet cotton swabs, whereas lower cells were fixed with $4 \%$ paraformaldehyde for $20 \mathrm{~min}$ and stained with crystal violet for $30 \mathrm{~min}$. Micrographs of six fields were randomly obtained under an inverted microscope, and cells were counted. Three independent experiments were performed thrice.

\section{Cell survival ratios assay}

HUVECs were cultured in serum-free medium containing different concentrations of $\mathrm{H}_{2} \mathrm{O}_{2}$ for $4 \mathrm{~h}$. Survival ratios were tested by CCK- 8 assay according to instruction. Next, cells cultured in serum-free medium were incubated within PBS or different concentrations $(0.1,0.3$, and $1 \mu \mathrm{g} / \mathrm{mL})$ of ephrin-B2/Fc for $2 \mathrm{~h}$, then 0.3 $\mathrm{mmol} / \mathrm{L} \mathrm{H}_{2} \mathrm{O}_{2}$ was added for another $4 \mathrm{~h}$. Cell survival ratios were also tested using CCK-8 kit.

\section{Western blot}

Cells were treated with different ephrin-B2/ Fc concentrations for $0,5,20$, and $60 \mathrm{~min}$ and $3 \mathrm{~h}$ and were lysed with RIPA buffer supplemented with protease inhibitors. Protein concentrations were measured using bicinchoninic acid (BCA) method. Equal amounts of proteins were separated with SDS-PAGE and then electrophoretically transferred to nitrocellulose membranes. Membranes were blocked in $5 \%$ bovine serum albumin for $1 \mathrm{~h}$ at room temperature and then incubated overnight with primary antibodies diluted in Tris-buffered saline with Tween-20 (TBS-T) at $4{ }^{\circ} \mathrm{C}$. All primary antibodies were diluted at 1:1000 except for anti-c-Myc antibody, which was diluted at ratio of 1:800. Membranes were washed thrice with TBS-T buffer and incubated with corresponding secondary antibodies diluted (1:5000) in TBS-T. Bound antibodies were detected through chemiluminescence (Pierce). Quantity One (version 4.4) was used for quantitative analysis.

\section{Data analysis and statistics}

All assays were performed in three separate experiments conducted in triplicate. Results were reported as mean \pm standard error of the mean (SEM) of three independent experiments. Comparisons were performed using two-tailed paired Student's t-test. ${ }^{*} p<0.05,{ }^{*} p<$ 0.01 , and $* * * p<0.001$.

\section{CONFLICTS OF INTEREST}

The authors declare no conflicts of interest.

\section{FUNDING}

This work was supported by National Natural Science Foundation of China (Grant No.: 81272921, 81670542, 81370160) and Key Projects of Science and Technology Plan of Fujian Province (Grant No.: 2013D024).

\section{REFERENCES}

1. Folkman J. Tumor angiogenesis: therapeutic implications. $\mathrm{N}$ Engl J Med. 1971; 285:1182-6. doi: 10.1056/ NEJM197111182852108.

2. Folkman J. What is the evidence that tumors are angiogenesis dependent? J Natl Cancer Inst. 1990; 82:4-6.

3. Paez-Ribes M, Allen E, Hudock J, Takeda T, Okuyama H, Vinals F, Inoue M, Bergers G, Hanahan D, Casanovas O. Antiangiogenic therapy elicits malignant progression of tumors to increased local invasion and distant metastasis. Cancer Cell. 2009; 15:220-31. doi: 10.1016/j. ccr.2009.01.027. 
4. Wang J, Li G, Wang Y, Tang S, Sun X, Feng X, Li Y, Bao G, Li P, Mao X, Wang M, Liu P. Suppression of tumor angiogenesis by metformin treatment via a mechanism linked to targeting of HER2/HIF-1alpha/VEGF secretion axis. Oncotarget. 2015; 6:44579-92. doi: 10.18632/ oncotarget.6373.

5. Ebos JM, Kerbel RS. Antiangiogenic therapy: impact on invasion, disease progression, and metastasis. Nat Rev Clin Oncol. 2011; 8:210-21. doi: 10.1038/nrclinonc.2011.21.

6. Zhang X, Tang J, Zhi X, Xie K, Wang W, Li Z, Zhu Y, Yang $\mathrm{L}, \mathrm{Xu} \mathrm{H}, \mathrm{Xu} \mathrm{Z}$. miR-874 functions as a tumor suppressor by inhibiting angiogenesis through STAT3/VEGF-A pathway in gastric cancer. Oncotarget. 2015; 6:1605-17. doi: 10.18632/oncotarget.2748.

7. Gale NW, Yancopoulos GD. Growth factors acting via endothelial cell-specific receptor tyrosine kinases: VEGFs, angiopoietins, and ephrins in vascular development. Genes Dev. 1999; 13:1055-66.

8. Zhang G, Brady J, Liang WC, Wu Y, Henkemeyer M, Yan M. EphB4 forward signalling regulates lymphatic valve development. Nat Commun. 2015; 6:6625. doi: 10.1038/ ncomms 7625 .

9. Yancopoulos GD, Davis S, Gale NW, Rudge JS, Wiegand SJ, Holash J. Vascular-specific growth factors and blood vessel formation. Nature. 2000; 407:242-8. doi: $10.1038 / 35025215$.

10. Wang HU, Chen ZF, Anderson DJ. Molecular distinction and angiogenic interaction between embryonic arteries and veins revealed by ephrin-B2 and its receptor Eph-B4. Cell. 1998; 93:741-53. doi: 10.1016/s0092-8674(00)81436-1.

11. Soda Y, Myskiw C, Rommel A, Verma IM. Mechanisms of neovascularization and resistance to anti-angiogenic therapies in glioblastoma multiforme. J Mol Med (Berl). 2013; 91:439-48. doi: 10.1007/s00109-013-1019-z.

12. Sawamiphak S, Seidel S, Essmann CL, Wilkinson GA, Pitulescu ME, Acker T, Acker-Palmer A. Ephrin-B2 regulates VEGFR2 function in developmental and tumour angiogenesis. Nature. 2010; 465:487-91. doi: 10.1038/ nature08995.

13. Kandouz M. The Eph/Ephrin family in cancer metastasis: communication at the service of invasion. Cancer Metastasis Rev. 2012; 31:353-73. doi: 10.1007/s10555-012-9352-1.

14. Nakada $M$, Anderson EM, Demuth $T$, Nakada $S$, Reavie LB, Drake KL, Hoelzinger DB, Berens ME. The phosphorylation of ephrin-B2 ligand promotes glioma cell migration and invasion. Int J Cancer. 2010; 126:1155-65. doi: 10.1002/ijc.24849.

15. Alam SK, Yadav VK, Bajaj S, Datta A, Dutta SK, Bhattacharyya $M$, Bhattacharya S, Debnath S, Roy S, Boardman LA, Smyrk TC, Molina JR, Chakrabarti S, et al. DNA damage-induced ephrin-B2 reverse signaling promotes chemoresistance and drives EMT in colorectal carcinoma harboring mutant p53. Cell Death Differ. 2016; 23:707-22. doi: 10.1038/cdd.2015.133.
16. Kimura M, Kato Y, Sano D, Fujita K, Sakakibara A, Kondo N, Mikami Y, Tsukuda M. Soluble form of ephrinB2 inhibits xenograft growth of squamous cell carcinoma of the head and neck. Int J Oncol. 2009; 34:321-7.

17. Oweida A, Bhatia S, Hirsch K, Calame D, Griego A, Keysar S, Pitts T, Sharma J, Eckhardt G, Jimeno A, Wang XJ, Parkash G, Califano J, et al. Ephrin-B2 overexpression predicts for poor prognosis and response to therapy in solid tumors. Mol Carcinog. 2016; 56:1189-1196. doi: 10.1002/ mc. 22574 .

18. Drucker A, Arnason T, Yan SR, Aljawad M, Thompson K, Huang WY. Ephrin b2 receptor and microsatellite status in lymph node-positive colon cancer survival. Transl Oncol. 2013; 6:520-7.

19. Sharma GK, Dhillon VK, Masood R, Maceri DR. Overexpression of EphB4, EphrinB2, and epidermal growth factor receptor in papillary thyroid carcinoma: A pilot study. Head Neck. 2015; 37:964-9. doi: 10.1002/hed.23694.

20. Shibuya M. Vascular endothelial growth factor and its receptor system: physiological functions in angiogenesis and pathological roles in various diseases. J Biochem. 2013; 153:13-9. doi: 10.1093/jb/mvs136.

21. Moens S, Goveia J, Stapor PC, Cantelmo AR, Carmeliet P. The multifaceted activity of VEGF in angiogenesis Implications for therapy responses. Cytokine Growth Factor Rev. 2014; 25:473-82. doi: 10.1016/j.cytogfr.2014.07.009.

22. Wang Y, Nakayama M, Pitulescu ME, Schmidt TS, Bochenek ML, Sakakibara A, Adams S, Davy A, Deutsch U, Luthi U, Barberis A, Benjamin LE, Makinen T, et al. Ephrin-B2 controls VEGF-induced angiogenesis and lymphangiogenesis. Nature. 2010; 465:483-6. doi: 10.1038/ nature09002.

23. Carmeliet P. Angiogenesis in life, disease and medicine. Nature. 2005; 438:932-6. doi: 10.1038/nature04478.

24. Germain S, Eichmann A. VEGF and ephrin-B2: a bloody duo. Nat Med. 2010; 16:752-4. doi: 10.1038/nm0710-752.

25. Maekawa H, Oike Y, Kanda S, Ito Y, Yamada Y, Kurihara H, Nagai R, Suda T. Ephrin-B2 induces migration of endothelial cells through the phosphatidylinositol-3 kinase pathway and promotes angiogenesis in adult vasculature. Arterioscler Thromb Vasc Biol. 2003; 23:2008-14. doi: 10.1161/01.atv.0000096655.56262.56.

26. Steinle JJ, Wu MH, Meininger CJ, Granger HJ. Ephrin B2 stimulation of microvascular endothelial cells causes cell migration via PKB/Akt. Faseb Journal. 2002; 16:A89-A.

27. Azab F, Azab AK, Maiso P, Calimeri T, Flores L, Liu Y, Quang P, Roccaro AM, Sacco A, Ngo HT, Zhang Y, Morgan BL, Carrasco RD, et al. Eph-B2/ephrin-B2 interaction plays a major role in the adhesion and proliferation of Waldenstrom's macroglobulinemia. Clin Cancer Res. 2012; 18:91-104. doi: 10.1158/1078-0432.ccr-11-0111.

28. Kim I, Ryu YS, Kwak HJ, Ahn SY, Oh JL, Yancopoulos GD, Gale NW, Koh GY. EphB ligand, ephrinB2, suppresses the VEGF- and angiopoietin 1-induced Ras/mitogen-activated 
protein kinase pathway in venous endothelial cells. FASEB J. 2002; 16:1126-8. doi: 10.1096/fj.01-0805fje.

29. Milkiewicz M, Ispanovic E, Doyle JL, Haas TL. Regulators of angiogenesis and strategies for their therapeutic manipulation. International Journal of Biochemistry \& Cell Biology. 2006; 38:333-57. doi: 10.1016/j. biocel.2005.10.006.

30. Fuller T, Korff T, Kilian A, Dandekar G, Augustin HG. Forward EphB4 signaling in endothelial cells controls cellular repulsion and segregation from ephrinB2 positive cells. J Cell Sci. 2003; 116:2461-70. doi: 10.1242/jcs.00426.

31. Hamada $\mathrm{K}$, Oike $\mathrm{Y}$, Ito $\mathrm{Y}$, Maekawa $\mathrm{H}$, Miyata $\mathrm{K}$, Shimomura T, Suda T. Distinct roles of ephrin-B2 forward and EphB4 reverse signaling in endothelial cells. Arterioscler Thromb Vasc Biol. 2003; 23:190-7.

32. Steinle JJ, Meininger CJ, Chowdhury U, Wu GY, Granger HJ. Role of ephrin B2 in human retinal endothelial cell proliferation and migration. Cell Signal. 2003; 15:1011-7.

33. Ehlken C, Martin G, Lange C, Gogaki EG, Fiedler U, Schaffner F, Hansen LL, Augustin HG, Agostini HT. Therapeutic interference with EphrinB2 signalling inhibits oxygen-induced angioproliferative retinopathy. Acta Ophthalmol. 2011; 89:82-90. doi: 10.1111/j.1755-3768.2009.01609.x.

34. Foubert P, Squiban C, Holler V, Buard V, Dean C, Levy BI, Benderitter M, Silvestre JS, Tobelem G, Tamarat R. Strategies to Enhance the Efficiency of Endothelial Progenitor Cell Therapy by Ephrin B2 Pretreatment and Coadministration with Smooth Muscle Progenitor Cells on Vascular Function During the Wound-Healing Process in Irradiated or Nonirradiated Condition. Cell Transplant. 2015; 24:1343-61. doi: 10.3727/096368913X672064.

35. Mansson-Broberg A, Siddiqui AJ, Genander M, Grinnemo KH, Hao X, Andersson AB, Wardell E, Sylven C, Corbascio
M. Modulation of ephrinB2 leads to increased angiogenesis in ischemic myocardium and endothelial cell proliferation. Biochem Biophys Res Commun. 2008; 373:355-9. doi: 10.1016/j.bbrc.2008.06.036.

36. Martin-Almedina S, Martinez-Corral I, Holdhus R, Vicente A, Fotiou E, Lin S, Petersen K, Simpson MA, Hoischen A, Gilissen C, Jeffery H, Atton G, Karapouliou C, et al. EPHB4 kinase-inactivating mutations cause autosomal dominant lymphatic-related hydrops fetalis. J Clin Invest. 2016; 126:3080-8. doi: 10.1172/JCI85794.

37. Lisle JE, Mertens-Walker I, Stephens CR, Stansfield SH, Clements JA, Herington AC, Stephenson SA. Murine, but not human, ephrin-B2 can be efficiently cleaved by the serine protease kallikrein-4: implications for xenograft models of human prostate cancer. Exp Cell Res. 2015; 333:136-46. doi: 10.1016/j.yexcr.2015.02.014.

38. Kida Y, Ieronimakis N, Schrimpf C, Reyes M, Duffield JS. EphrinB2 reverse signaling protects against capillary rarefaction and fibrosis after kidney injury. J Am Soc Nephrol. 2013; 24:559-72. doi: 10.1681/ASN.2012080871.

39. Rath T, Baker K, Dumont JA, Peters RT, Jiang H, Qiao SW, Lencer WI, Pierce GF, Blumberg RS. Fc-fusion proteins and FcRn: structural insights for longer-lasting and more effective therapeutics. Crit Rev Biotechnol. 2015; 35:23554. doi: 10.3109/07388551.2013.834293.

40. Takai T. Fc receptors and their role in immune regulation and autoimmunity. J Clin Immunol. 2005; 25:1-18. doi: 10.1007/s10875-005-0353-8.

41. Roopenian DC, Akilesh S. FcRn: the neonatal Fc receptor comes of age. Nat Rev Immunol. 2007; 7:715-25. doi: $10.1038 /$ nri2 155 .

42. Ozlu N, Akten B, Timm W, Haseley N, Steen H, Steen JA. Phosphoproteomics. Wiley Interdiscip Rev Syst Biol Med. 2010; 2:255-76. doi: 10.1002/wsbm.41. 